\title{
Determinates of Customer Services Delivery in Civil Service Office: In Case of Sheka Zone Civil Service Office
}

\author{
Walelign Gebito Tekalign \\ Lecturer, Department of Management, Mizan Tepi University, Ethiopia
}

\begin{abstract}
Providing quality service to customer is very important for the success of any service delivered organization. Therefore they are very important for the customers too. This study aimed to examine the determinants of customer service delivery of civil service office in sheka zone civil service office. The study was conducted from June 2020 to august 2020. A questionnaire was designed to collect the data on the determinant factors like office bureaucracy, procrastination, absence of leader or manager in office, sociability of leader, time limitation that given for each server, time scheduled program manager or leader contact with customer, transparency and customer service delivery. The study was used explanatory research design and both primary and secondary data was used to conduct this study. Simple random sampling technique was used to select the office and the data was collected through convince method to infer the target population of the study. The data was collected from the customers of sheka zone civil service office. The collected data was analyzed by SPSS 20 Version. Descriptive and explanatory statistics was used to analyze the data and a sample of 385 customers was used to collect the data. Besides, descriptive statistical tools like maximum, minimum, mean and standard deviation. The study revealed that majority of the respondents feel agreed on determinant factors influence the service delivery. Inferential statistical methods like correlation analysis was used to assess the relationship between determinant factors and customer service delivery, multiple linear regression analysis also was employed to examine the influence of determinant factors on customer service delivery by using primary data collected through five scale likert questionnaire. Based on the findings of the study, from determinant factors of customer service delivery office bureaucracy, procrastination and absence of leader or manager in office have a negative and sociability of leader, time limitation that given for each server, time scheduled program manager or leader contact with customer and transparency have a positive and statistically significant correlation with customer service delivery. The multiple linear regression analysis $\left(\mathrm{R}^{2}\right)$ implies that about $88.1 \%$ shows that the determinant factors determine the variation of customer service delivery of sheka zone civil service office. Also the regression result revealed that all explanatory variables have a statistically significant effect on customer service delivery. This indicated that determinant factors determine customer service delivery of sheka zone civil service office. Therefore, sheka zone civil service office should give primacy to avoid those bottlenecks appropriately to provide continuously as an indispensable tool to improve and maintain sustainable customer service delivery.
\end{abstract}

Keywords:customer service delivery, office bureaucracy, procrastination, absence of leader or manager in office, sociability of leader, time limitation that given for each server, time scheduled program manager or leader contact with customer and transparency

DOI: $10.7176 / \mathrm{EJBM} / 13-7-01$

Publication date: April $30^{\text {th }} 2021$

\section{CHAPTER ONE}

\section{INTRODUCTION}

Sheka zone was found in south western part of Ethiopia, $698 \mathrm{~km}$ far away from the capital city of Ethiopia. The total area coverage of $238750 \mathrm{~km}^{2}$ and its total population projection was approximately 300,000 in numbers. From the total land scape coverage $61 \%$ was covered by rain forest and the rain forest was registered and recognized by UNESCO. Sheka zone has consists of two city administration and three woredas, those are Tepi and Masha city administrations and yeki, anderacha and masha woreda were avail in this zone.

Certainly customer's service deliver is providing appropriate service for their customers at right quality, right time and by the right person at right place. Most of customer service deliver problem happen in both private and public sectors due to low quality, it don't provide their service at right time, it don't deliver their service by right person who has specialists at related filed or related subject matter and don't provide their service at right respective place.

In most of civil service customers service delivery affected by so many factors, like most of the civil servant given priority for personal problem rather than public problems, also most of civil servant in our country Ethiopia stay at office by fearing their leader or manager than loving their job, they come up to office in time because of fearing their leader than respecting their work.

In sheka zone civil service customer service deliver also affected by many problems, like the office 
environments have highly apply bureaucracy to serving customers in the office even from the beginning they ask the customer's name up to final dealing with the problem they pass so many challenges even if unexpected world also inculcated, procrastination is the most problem in sheka zone office environment that mean the leader or manager said come up afternoon, tomorrow and the like act.., absence of leader or manager from office without representing other person, absence of sociable interaction of leader with their peer and customers, absence of limited time given to each customer, absence of clear time schedule when the leader serve their customers in office and lack of transparency that means most of the leader has not openly announced what kinds issue is solved by them and other respective leaders or managers.

\subsection{Objectives of the study}

This study was both general and specific objective are indoctrinated

\subsubsection{General objective}

The main objective of this study was to examine determinates of customers service delivery in sheka zone civil service office.

\subsubsection{Specific objectives}

The specific objectives of this study were the following:-

$>$ Office bureaucracy has statistically significantly influence customer service delivery of civil service office in sheka zone.

$>$ Procrastination has statistically significantly influence customer service delivery of civil service office in sheka zone.

$>$ Absence of manager or leader in office has statistically significantly influence customer service delivery of civil service office in sheka zone.

$>$ Sociability of the leader or manager has statistically significantly influence customer service delivery of civil service office in sheka zone.

$>$ Time limitation that given for each customer has statistically significantly influence customer service delivery of civil service office in sheka zone.

$>$ Time schedule that the leader or manager contact with customer has statistically significantly influence customer service delivery of civil service office in sheka zone.

$>$ Transparency has statistically significantly influence customer service delivery of civil service office in sheka zone.

\subsection{Hypothesis of the study}

The proposed study is to prove or disprove the following hypotheses which have been prepared based on conceptual framework of the study:

Ho1: Office bureaucracy has no statistically significantly influence customer service delivery of civil service in sheka zone.

Ho2: Procrastination has no statistically significantly influence customer service delivery of civil service in sheka zone.

Ho3: Absence of manager in office has no statistically significantly influence customer service delivery of civil service in sheka zone.

Ho4: Sociability of leader or manager has no statistically significantly influence customer service delivery of civil service in sheka zone.

Ho5: Time limitation that given for each customer has no statistically significantly influence customer service delivery of civil service in sheka zone.

Ho6: Time schedule that the leader or manager contact with customer has no statistically significantly influence customer service delivery of civil service in sheka zone.

Ho7: Transparency has no statistically significantly influence customer service delivery of civil service in sheka zone.

\section{CHAPTER TWO \\ LITERATURE REVIEW}

\subsection{Theoretical review}

\subsubsection{Concept of customer service}

In business term customer is someone who can buy or purchase the goods and services of the company or organization. Customers have the ability to enhance the reputation of the organization and contribute to the business growth and expansion of the business. According to Machado et al. (2012:4), a customer refers to consumers who buy goods and services and further mention that customers are people who interact in the market place, Customers could best be described as those who use the output of work, the end users of products or services. 


\subsubsection{Service delivery}

Service delivery is providing service to customer through incentives, accountability arrangements, and rules that affect the way key actors including policy makers and provider organizations and their managers and staff are held accountable for their behaviors and ability to deliver high-quality services with efficiency and responsiveness. Since the organization managers believe that the power of quality guarantees high profits in organization, organization try to understand how to keep the quality level high at every point within production, manufacturing, and even providing services (Ghylin et al. 2008).

\subsubsection{Quality service delivery}

Quality service delivery is the customers own perception of the service based on different factors contributing to the service, from the process to the final outcome. According to Grönroos (2001), "quality is what customers perceive". Customers buying service consider everything that contributes to the process and the final outcome in making their assessments of the service. However the subjective assessment of the actual service experiences is the customer perceived service quality.

\subsection{Conceptual Framework Independent variables}

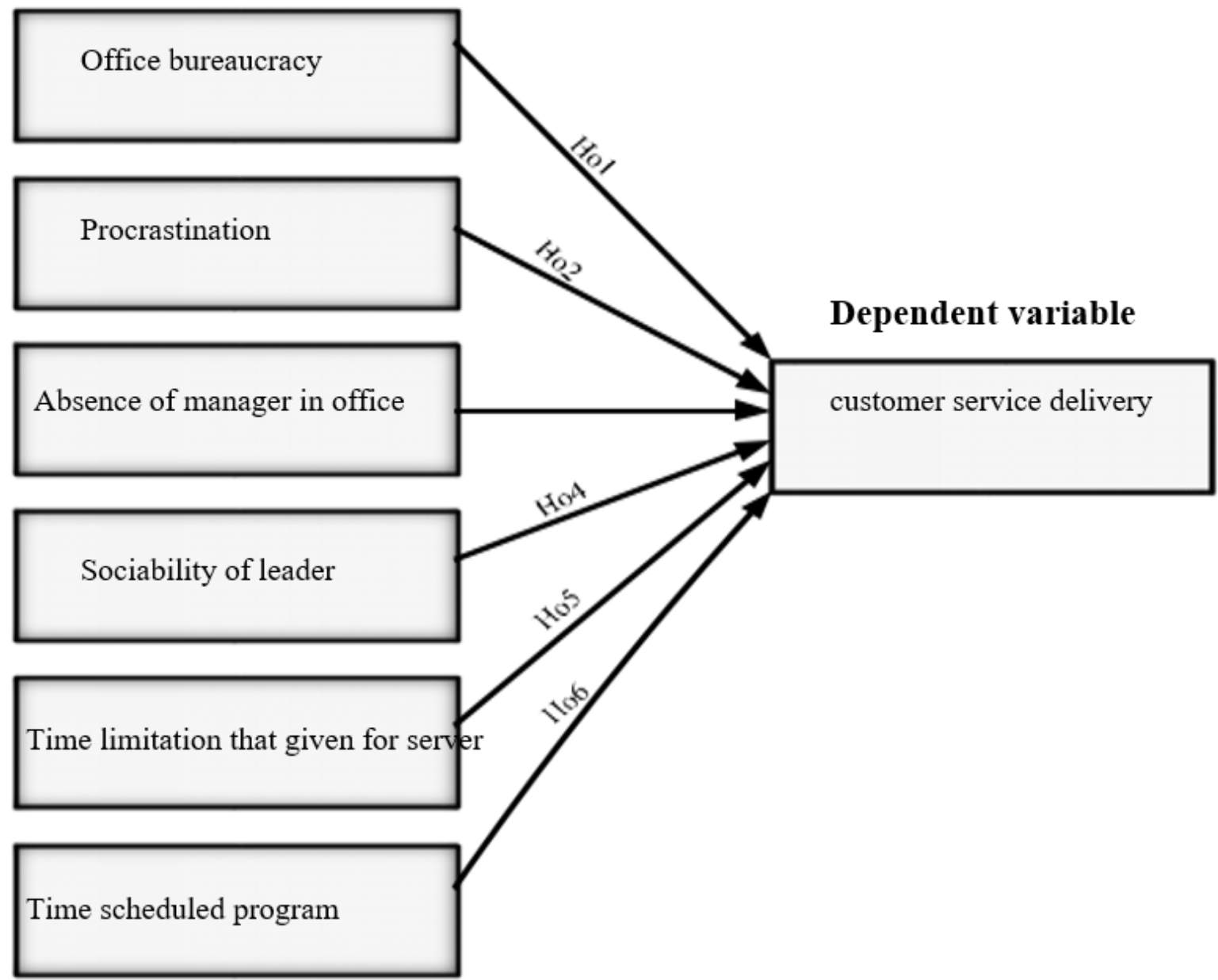

Lack of transparency

Figure 1 Conceptual Framework of the study

\section{CHAPTER THREE}

\section{RESEARCH METHDOLOGY}

3.1 Methodology of the study

The main concern of this study was to examine the determinate factors on civil service customer's services delivery. So it utilize explanatory research design because of to determine how much the independent variables influence the dependent variable, under this study there is seven independent variables those are office bureaucracy, procrastination, absence of leader or manager in office, sociability of leaders, time limitation given 
for each server, time scheduled program the manager or leader contact with customer and transparency and one dependent variable customers service delivery.

For infinite population the study was used according to Kothari (2004). Since p is actually what we are trying to estimate, then what value we should assign to it? One method may be to take the value of $p=0.5$ in which case "n" will be the maximum and the sample will yield at least the desired precision. This was the most conservative sample size.

Hence, with 95 percent confidence interval and 5 percent of acceptable error (e), the representative number of samples were determined by using the following formula.

$$
\begin{aligned}
& \mathrm{n}=\frac{\mathrm{z}^{2} . \mathrm{p} . \mathrm{q}}{\mathrm{e}^{2}} \\
& \mathrm{n}=\frac{1.96^{2} \times 0.5 \times 0.5}{}=\underline{0.05^{2}} \underline{\mathbf{3 8 5}} \text { Where; } \\
& \mathrm{n}=\text { the required sample size } \\
& \mathrm{Z}=\text { confidence level at } 95 \%(1.96) \text { on the table } \\
& \mathrm{E}=\text { margin error }(100 \%-95 \%) 0.05
\end{aligned}
$$

Source; Kothari (2004, p. 179).

The data was collected through Five-point Likert scale questionnaire (5-Strongly Agreed, 4- Agree, 3-nutral, 2- Disagree, 1- Strongly Disagree) that best describes the extent to which the respondents agree with each items in the questionnaire was used. Stratified random sampling would use to group the office sectors and convenes sampling was utilized to collect data from the respondents. Primary and secondary data was collected then collected data must be analyzed. Data was be fed into SPSS (statistical package for social science) was used to analyze collected data for easy analysis.

The equation of multiple liner regression model is

$$
\begin{aligned}
\mathrm{Y}= & \beta_{\mathrm{O}}+\beta_{1} \mathrm{X}_{1}+\beta_{2} \mathrm{X}_{2}+\beta_{3} \mathrm{X}_{3}+\beta_{4} \mathrm{X}_{4}+\beta_{5} \mathrm{X}_{5}+\beta 6 \mathrm{X} 6+\beta 7 \mathrm{X} 7+\varepsilon \\
& \text { Where } \mathrm{Y}=\text { Customer service deliver } \\
& \beta_{1} \text { to } \beta 5=\text { Coefficient of independent variables } \\
& \mathrm{X}_{1} \text { to } \mathrm{x} 5=\text { Independent variables } \\
& \varepsilon=\text { Error term of the model }
\end{aligned}
$$

\section{CHAPTHER FOUR}

\section{RESULTS AND DISCUSSION}

\subsection{Descriptive analysis}

Table 1 Five Scaled Likert Criterion

\begin{tabular}{|l|l|l|}
\hline No. & Mean range & Response Option \\
\hline 1 & 1 to 1.80 & Strongly disagree \\
\hline 2 & 1.8 to 2.6 & Disagree \\
\hline 3 & 2.6 to 3.4 & Neutral \\
\hline 4 & 3.4 to 4.20 & Agree \\
\hline 5 & 4.2 to 5.00 & Strongly Agree \\
\hline
\end{tabular}

Source: Al-Sayaad et al. (2006, as cited by Bassam, 2013).

Table 2 summary of descriptive analysis

\begin{tabular}{|l|l|l|}
\hline No & Determinant factors & Average mean \\
\hline 1 & office bureaucracy & 3.24 \\
\hline 2 & procrastination & 3.30 \\
\hline 3 & absence of leader or manager in office & 3.40 \\
\hline 4 & sociability of leaders or manager & 3.27 \\
\hline 5 & time limitation given for each server & 3.58 \\
\hline 6 & time scheduled program the manager or leader contact with customer & 3.77 \\
\hline 7 & transparency & 3.42 \\
\hline 8 & customers service delivery & 1.67 \\
\hline
\end{tabular}

Source :( field Survey, 2020) 


\section{2 inferential analysis}

4.2.1 Pearson correlation analysis result

Table 3 Pearson correlation analysis result

\begin{tabular}{|c|c|c|c|c|c|c|c|c|c|}
\hline . & & 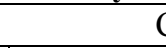 & Correlations & & & & & & \\
\hline & & $\begin{array}{l}\text { Office } \\
\text { bureaucracy }\end{array}$ & Procrastination & $\begin{array}{l}\text { Absence } \\
\text { of leader } \\
\text { in office }\end{array}$ & $\begin{array}{l}\text { Sociability } \\
\text { of leader }\end{array}$ & $\begin{array}{l}\text { Time } \\
\text { limitation } \\
\text { for server }\end{array}$ & $\begin{array}{l}\text { Time } \\
\text { schedule }\end{array}$ & Transparency & $\begin{array}{l}\text { Customer } \\
\text { service } \\
\text { delivery }\end{array}$ \\
\hline $\begin{array}{l}\text { Office } \\
\text { bureaucracy }\end{array}$ & $\begin{array}{l}\text { Pearson } \\
\text { Correlation }\end{array}$ & 1 & & & & & & & \\
\hline & \begin{tabular}{|l} 
Sig. \\
tailed $)$
\end{tabular} & & & & & & & & \\
\hline & $\mathrm{N}$ & 385 & & & & & & & \\
\hline Procrastination & $\begin{array}{l}\text { Pearson } \\
\text { Correlation }\end{array}$ & $-.155^{* *}$ & 1 & & & & & & \\
\hline & \begin{tabular}{|l} 
Sig. \\
tailed $)$
\end{tabular} & .000 & & & & & & & \\
\hline & $\mathrm{N}$ & 385 & 385 & & & & & & \\
\hline $\begin{array}{l}\text { Absence o } \\
\text { leader in office }\end{array}$ & $\begin{array}{l}\text { Pearson } \\
\text { Correlation }\end{array}$ & $.200^{* *}$ & $-.174^{* *}$ & 1 & & & & & \\
\hline & \begin{tabular}{|l|} 
Sig. \\
tailed)
\end{tabular} & .000 & .000 & & & & & & \\
\hline & $\mathrm{N}$ & 385 & 385 & 385 & & & & & \\
\hline $\begin{array}{l}\text { Sociability } 0 \\
\text { leader }\end{array}$ & $\begin{array}{l}\text { Pearson } \\
\text { Correlation }\end{array}$ & $.092^{* *}$ & $-.406^{* *}$ & $.332^{* *}$ & 1 & & & & \\
\hline & \begin{tabular}{|l|} 
Sig. \\
tailed)
\end{tabular} & .000 & .000 & .000 & & & & & \\
\hline & $\mathrm{N}$ & 385 & 385 & 385 & 385 & & & & \\
\hline $\begin{array}{l}\text { Time limitation } \\
\text { for server }\end{array}$ & $\begin{array}{l}n \text { Pearson } \\
\text { Correlation } \\
\end{array}$ & $-.240^{* *}$ & $.856^{* *}$ & $-.182^{* *}$ & $-329^{* *}$ & 1 & & & \\
\hline & \begin{tabular}{|l|} 
Sig. \\
tailed)
\end{tabular} & .000 & .000 & .000 & .000 & & & & \\
\hline & $\mathrm{N}$ & 385 & 385 & 385 & 385 & 385 & & & \\
\hline Time schedule & $\begin{array}{l}\text { Pearson } \\
\text { Correlation } \\
\end{array}$ & $-.441^{* *}$ & $.546^{* *}$ & $-123^{* *}$ & $-.078^{* *}$ & $.604^{* *}$ & 1 & & \\
\hline & \begin{tabular}{|l} 
Sig. \\
tailed $)$
\end{tabular} & .000 & .000 & .000 & .000 & .000 & & & \\
\hline & $\mathrm{N}$ & 385 & 385 & 385 & 385 & 385 & 385 & & \\
\hline Transparency & $\begin{array}{l}\text { Pearson } \\
\text { Correlation }\end{array}$ & $-.465^{* *}$ & $.587^{* *}$ & $-130^{* *}$ & $-.097^{* *}$ & $.654^{* *}$ & $.880^{* *}$ & 1 & \\
\hline & $\begin{array}{l}\text { Sig. } \\
\text { tailed) }\end{array}$ & .000 & .000 & .000 & .000 & .000 & .000 & & \\
\hline & $\mathrm{N}$ & 385 & 385 & 385 & 385 & 385 & 385 & 385 & \\
\hline $\begin{array}{l}\text { Customer } \\
\text { service } \\
\text { delivery }\end{array}$ & $\begin{array}{l}\text { Pearson } \\
\text { Correlation }\end{array}$ & $-.570^{* *}$ & $-.537^{* *}$ & $-.224^{* *}$ & $.201^{* *}$ & $.649^{* *}$ & $.836^{* *}$ & $.916^{* *}$ & 1 \\
\hline & $\begin{array}{l}\text { Sig. } \\
\text { tailed) }\end{array}$ & .000 & .000 & .000 & .000 & .000 & .000 & .000 & \\
\hline & $\mathrm{N}$ & 385 & 385 & 385 & 385 & 385 & 385 & 385 & 385 \\
\hline
\end{tabular}

Source :( field Survey, 2020)

\section{The relationship between office bureaucracy and customer service delivery}

According to the above table 12 , there is a significant negative relationship between office bureaucracy and customer service delivery $(\mathrm{r}=-.570, \mathrm{p}<0.01)$. According to Bhattacherjee the magnitude of correlation, there is moderate and negative relationship between office bureaucracy and customer service delivery.

The relationship between procrastination and customer service delivery

According to the above table 12, there is a significant negative relationship between procrastination and customer service delivery $(\mathrm{r}=-.537, \mathrm{p}<0.01)$. According to Bhattacherjee the magnitude of correlation, there is moderate 
and negative relationship between procrastination and customer service delivery.

The relationship between absence of leader in office and customer service delivery

From the above table 12, there is a significant negative relationship between absence of leader in office and customer service delivery $(\mathrm{r}=-.224, \mathrm{p}<0.01)$. According to Bhattacherjee the magnitude of correlation, there is weak and negative relationship between absence of leader in office and customer service delivery.

The relationship between sociability of leader and customer service delivery

From the above table 12, there is a significant positive relationship between sociability of leader and customer service delivery $(\mathrm{r}=-.201, \mathrm{p}<0.01)$. According to Bhattacherjee the magnitude of correlation, there is weak and positive relationship between sociability of leader and customer service delivery.

The relationship between time limitation that given for each customer and customer service delivery

According to the above table 12, there is a significant positive relationship between time limitation that given for each customer and customer service delivery $(\mathrm{r}=-.649, \mathrm{p}<0.01)$. According to Bhattacherjee the magnitude of correlation, there is strong and positive relationship between time limitation that given for each customer and customer service delivery.

The relationship between time schedule that the leader or manager contact with customer and customer service delivery

From the above table 12 , there is a significant positive relationship between time schedule that the leader or manager contact with customer and customer service delivery $(\mathrm{r}=-.836, \mathrm{p}<0.01)$. According to Bhattacherjee the magnitude of correlation, there is very strong and positive relationship between time schedule that the leader or manager contact with customer and customer service delivery.

The relationship transparency and customer service delivery

According to the above table 12, there is a significant positive relationship between transparency and customer service delivery $(\mathrm{r}=-.916, \mathrm{p}<0.01)$. According to Bhattacherjee the magnitude of correlation, there is very strong and positive relationship between transparency and customer service delivery.

4.2.2 Regression analysis

Table 4 Results showing coefficient of regression analysis

\begin{tabular}{|c|c|c|c|c|c|}
\hline \multicolumn{6}{|c|}{ Coefficients $a$} \\
\hline \multirow[t]{2}{*}{ Independent Variables } & \multicolumn{2}{|c|}{$\begin{array}{l}\text { Unstandardized } \\
\text { Coefficients }\end{array}$} & $\begin{array}{l}\text { Standardized } \\
\text { Coefficients }\end{array}$ & $\mathrm{T}$ & Sig. \\
\hline & $\mathrm{B}$ & Std. Error & Beta & & \\
\hline (Constant) & 1.879 & .282 & & 6.728 & .000 \\
\hline Office bureaucracy & -.504 & .059 & -.179 & -8.589 & .000 \\
\hline Procrastination & -.108 & .043 & -.091 & -2.511 & .012 \\
\hline $\begin{array}{l}\text { Absence of leader or manager } \\
\text { in office }\end{array}$ & -.076 & .034 & -.043 & -2.220 & .027 \\
\hline Sociability of leader & .090 & .033 & .058 & 2.759 & .006 \\
\hline $\begin{array}{l}\text { Time limitation given for } \\
\text { each customer }\end{array}$ & .255 & .048 & .198 & 5.367 & .000 \\
\hline $\begin{array}{l}\text { Time schedule that the } \\
\text { manager or leader contact } \\
\text { with customer }\end{array}$ & .111 & .048 & .088 & 2.326 & .021 \\
\hline Transparency & .690 & .041 & .679 & 16.703 & .000 \\
\hline
\end{tabular}

Source: (filed survey, 2020)

Taking in to consideration the results from table 4, the regression equation for the study was as follows:

$Y=1.879+-.504 X_{1}+. .108 X_{2}+-.076 X_{3}+.090 X_{4}+.255 X_{5}+.111 X_{6}+.690 X_{7}+.282$

Interpretation:

Keeping all other variables Constant;

- For every increment change on office bureaucracy, the percentage of customer service delivery decreases by 50.4 (percent).

- For every increment change on procrastination, the percentage of customer service delivery decreases by 10.8 (percent).

- For every increment change on absence of leader in office, the percentage of customer service delivery decreases by 7.6 (percent).

- For every increment change on sociability of leader, the percentage of customer service delivery increases by 9 (percent).

- For every increment change on time limitation given for each customer, the percentage of customer service delivery increases by 25.5 (percent). 
- For every increment change on time schedule that the manager or leader contact with customer, the percentage of customer service delivery increases by 11.1 (percent).

- For every increment change on transparency, the percentage of customer service delivery increases by 69 (percent).

The model of customer service delivery can be written by including error term $(\varepsilon)$ as:

Customer service delivery $=1.879+-.504$ office bureaucracy.+ .108 procrastination +-.076 absence of leader in office +.090 sociability of leader +.255 time limitation given for each customer +.111 time schedule that the manager or leader contact with customer +.690 transparency +.282

Table 5 Summary of hypothesis test result

\begin{tabular}{|c|c|c|c|}
\hline No & Hypothesis & Tool & Result \\
\hline $\mathrm{H}_{\mathrm{a}} 1$ & $\begin{array}{l}\text { Office bureaucracy has statistically significant effect on the Customer } \\
\text { service delivery of Sheka zone civil service office. }\end{array}$ & Regression & Accepted \\
\hline $\mathrm{H}_{\mathrm{a}} 2$ & $\begin{array}{l}\text { Procrastination has statistically significant effect on the Customer } \\
\text { service delivery of Sheka zone civil service office. }\end{array}$ & Regression & Accepted \\
\hline $\mathrm{H}_{\mathrm{a}} 3$ & $\begin{array}{l}\text { Absence of leader or manager in office has statistically significant effect } \\
\text { on the Customer service delivery of Sheka zone civil service office. }\end{array}$ & Regression & Accepted \\
\hline $\mathrm{H}_{\mathrm{a}} 4$ & $\begin{array}{l}\text { Sociability of leader has statistically significant effect on the Customer } \\
\text { service delivery of Sheka zone civil service office. }\end{array}$ & Regression & Accepted \\
\hline $\mathrm{H}_{\mathrm{a}} 5$ & $\begin{array}{l}\text { Time limitation given for each customer has statistically significant } \\
\text { effect on the Customer service delivery of Sheka zone civil service } \\
\text { office. }\end{array}$ & Regression & Accepted \\
\hline $\mathrm{H}_{\mathrm{a}} 6$ & $\begin{array}{l}\text { Time schedule that the manager or leader contact with customer has } \\
\text { statistically significant effect on the Customer service delivery of Sheka } \\
\text { zone civil service office. }\end{array}$ & Regression & Accepted \\
\hline $\mathrm{H}_{\mathrm{a}} 7$ & $\begin{array}{l}\text { Transparency has statistically significant effect on the Customer service } \\
\text { delivery of Sheka zone civil service office. }\end{array}$ & Regression & Accepted \\
\hline
\end{tabular}

Source :( filed survey, 2020)

\section{CHAPTER FIVE}

\section{Summary of major finding, conclusion and recommendation}

\subsection{Summary of major finding}

Based on the analysis results of the study the following summaries are made accordingly: From the analysis result of descriptive statistics of the study, majority of the respondent were agreed about the seven factors determines customer service delivery those factors are (office bureaucracy, procrastination, absence of leader in office, sociability of leader, time limitation given for each customer, time schedule that the manager or leader contact with customer and transparency). Moreover, the findings from the descriptive statistics on customer service delivery indicate that majority of the customer were disagreed about the service delivery of sheka zone civil service office.

Also the result of Pearson correlation table 12 shows seven independent variables i.e. sociability of leader, time limitation given for each customer, time schedule that the manager or leader contact with customer and transparency are positive and office bureaucracy, procrastination and absence of leader in office are negative statistically significant relationship with dependent variable i.e. customer service delivery at 99 percent confidence level $(\mathrm{P}<0.01)$. The highest correlation is signified by transparency $(\mathrm{r}=0.916)$, time schedule that the manager or leader contact with customer $(\mathrm{r}=0.836)$, time limitation given for each customer $(\mathrm{r}=0.649)$, sociability of leader $(r=0.201)$, office bureaucracy $(r=-0.570)$, procrastination $(r=-0.537)$ and absence of leader in office $(\mathrm{r}=-0.224)$.

According to table 13 the analysis result of multiple linear regression of the seven determinant factors. The table result shows that the model test is significant with the R Square value of 0.881 ( 88.1 percent), it indicates that the variability of the customer service delivery of sheka zone civil service office explained by the variability of independent variables i.e. office bureaucracy, procrastination, absence of leader in office, sociability of leader, time limitation given for each customer, time schedule that the manager or leader contact with customer and transparency while, the remaining 11.9 (present) of the variability of customer service delivery of sheka zone civil service office may be explained by other factors.

Table 14 illustrate that coefficients of customer service delivery determinant factors. Thus on the other hand, the Beta coefficient for office bureaucracy $\left(\mathrm{X}_{1}\right)$ is $\beta_{1}=-0.504$ indicates the reduction of the customer service delivery up to $=-0.504$ on average by keeping the other variables constant, the Beta coefficient for 
procrastination $\left(\mathrm{X}_{2}\right)$ is $\beta_{2}=-0.108$ indicate the reduction of the customer service delivery up to -0.108 on average by keeping the other variables constant, the Beta coefficient for absence of leader in office $\left(\mathrm{X}_{3}\right)$ is $\beta_{3}=$ -0.076 indicate the reduction of the customer service delivery up to -0.076 on average by keeping the other variables constant, when the Beta coefficient for sociability of leader (X4) is $\beta 4=0.090$ indicates the growth of the customer service delivery up to 0.090 on average by keeping the other variables constant, when the Beta coefficient for time limitation given for each customer $\left(\mathrm{X}_{5}\right)$ is $\beta 5=0.255$ indicate the growth of the customer service delivery up to 0.255 on average by keeping the other variables constant as the model shows clearly, when the Beta coefficient for time schedule that the manager or leader contact with customer $\left(\mathrm{X}_{6}\right)$ is $\beta_{6}=0.111$ indicates the growth of the customer service delivery up to 0.111 on average by keeping the other variables constant and the Beta coefficient for transparency (X7) is $\beta 7=0.690$ indicates the growth of the customer service delivery up to 0.690 on average by keeping the other variables constant, the majority of the contribution to the customer service delivery is occupied by transparency.

Also table 14 analysis results of multiple linear regressions of the seven customer service delivery determinant factors, the p-value of each hypothesis should be either accepted or rejected with reference to 5 (percent) level of significance; i.e. the null hypothesis must be rejected if P-value is less than 0.05 other wise accept it. Based on this seven independent variables (office bureaucracy, procrastination, absence of leader in office, sociability of leader, time limitation given for each customer, time schedule that the manager or leader contact with customer and transparency) have statistically significant effect on the customer service delivery of sheka zone civil service office with a P-Value of $0.000,0.012,0.027,0.006,0.000,0.021$ and 0.000 respectively (Reject Ho if $\mathrm{p}<0.05$ ).

\subsection{Conclusion}

During the investigation the researcher used both descriptive and inferential statistics and based on the findings of the research the researcher made conclusions by outlining following points.

As the results of the descriptive statistics depicted most of the customers were agreed with the determinate factors ;- office bureaucracy, procrastination, absence of leader in office, sociability of leader, time limitation given for each customer, time schedule that the manager or leader contact with customer and transparency influence customer service delivery in sheka zone civil service office. This implies that the customers are served with pleasure in terms of office bureaucracy, procrastination, absence of leader in office, sociability of leader, time limitation given for each customer, time schedule that the manager or leader contact with customer and transparency influence the service that provided by sheka zone civil service office.

Seven determinant factors of customer service delivery have a negative, positive and statistically significant correlation with customer service delivery. The correlation between the dependent variable customer service delivery and the seven independent variables was with magnitude ranges of "weak and negative" (1), "weak and positive" (1) "moderate and negative" (2) and "strongly positive" (3) level of correlation.

the multiple linear regression analysis (The $\mathrm{R}$ square) implies that about 88.1 (percent) shows that the seven determinant factors of customer service delivery (office bureaucracy, procrastination, absence of leader in office, sociability of leader, time limitation given for each customer, time schedule that the manager or leader contact with customer and transparency) can determine the variation of the customer service delivery in sheka zone civil service office. Therefore, the researcher can convincingly conclude that the determinant factors have a significant influence on customer service delivery of sheka zone civil service office.

As far as the relative effects of an individual determinant factors on customer service delivery is concerned, the result of multiple linear regression coefficient shows that transparency has the highest beta value which indicates the most dominant effect in determining the variation of customer service delivery followed by time limitation given for each customer with a beta values of $(\beta 1=0.679 \& \beta 2=0.198)$ respectively.

The multiple linear regression analysis of the independent variables and dependent variables shows that seven explanatory variables (office bureaucracy, procrastination, absence of leader in office, sociability of leader, time limitation given for each customer, time schedule that the manager or leader contact with customer and transparency) have a statistically significant effect for predicting customer service delivery in sheka zone civil service office.

\subsection{Recommendations}

This study has demonstrated that the determinate of customer service delivery in sheka zone civil service office. In light of the findings and conclusions made above, the following possible recommendations are suggested as being valuable to the office for improving or enhancing customer service delivery. This can be enhanced and developed through the following:

$>\quad$ In sheka zone civil service office their lack of transparency avail. So it is advisable to all sheka zone civil service office to announce feasible duties of each leaders what he/she to do in office and what kinds of 
problems are directly the customer deal with them.

$>\quad$ There is no properly stipulated time limitation that each customer consumed to deal their problem with each leader or manager in all sheka zone civil service office. So for all sheka zone civil service office would appropriately arrange the time limitation schedule for each customer will be serve in each office.

$>\quad$ Without well scheduled program that the leader or manager contact with in their office influence service delivery negatively, then all the sheka zone civil service office would notify the weekly time schedule that the customer will contact with them directly.

$>$ Mostly the leader or manager that holed the position in sheka zone civil service office shows absence of social interaction with customer and other office employees, then each of the leader or manager that holed the position in sheka zone civil service office would increase their social interaction with customer and increase their synergetic effort with their peers, this leads to increase the satisfaction of customer service delivery in sheka zone civil service office.

$>\quad$ In sheka zone civil service office mostly customer service delivery delayed due to procrastination act of leader or manager, so the office leader or manager of sheka zone civil service office would perform their tasks based on the office planned time schedule appropriately.

$>$ predominantly most of the leader or manager in sheka zone civil service not avail in office during the working time by due to several reason, then sheka zone administer would give impasses for this kind of behave leader apply autocratic type of leadership to shape their behaviors in office.

$>$ There is unnecessary bureaucracy applied in sheka zone civil service office environments. Then sheka zone administer would give focus on restructure the office environment in order to reduce unnecessary bureaucracy that determine customer service negatively.

$>$ Generally, sheka zone civil service office leaders or managers need short term training both (on the job and off the job training) in order to enhance customer service deliver in office environment and to increase the satisfaction level of customer by providing service by right person, at right time, at right place and with high quality.

\section{Reference}

Adeyemi, T.O. (2009). Inferential Statistics for Social and Behavioral Research. Research Journal of Mathematics and Statistics 1(2): 47-54, ISSN: 2040-7505.

Al-Sayaad, J., Rabea, A., Samrah, A. (2006). Statistics for Economics and Administration Studies. Dar Hafez, Jeddah, Kingdom of Saudi Arabia. In Bassam, T.(2013). A Model for Measuring Service Quality in InternetBased Services. Brunel University, Uxbridge, Middlesex, UK.

Bhattacherjee, A. (2012). Social Science research principle, methods and practices.

Burns, A., \& Burns, R. (2008). Basic Marketing Research (2 ${ }^{\text {nd }}$ ed.). New Jersey: Pearson Education.

Coetzee, O. (2003). The Relationship between Personality Variables and Work Performance of Credit Controllers in a Bank. Pretoria.

Field. (2009). Discovering Statistics Using SPSS: (3rd ed.). SAGE publications ltd.

Ghylin, K.M., Green, B. D., Drury, C. G., Chen, J., Schultz ,J.L., Uggirala, A., Abraham, J.K. \& Lawson, T.A. (2006). Clarifying the dimensions of four concepts of quality, Theoretical Issues in Ergonomics Science, Vol. 9, Number 1, p.73-94.

Grönroos, C. (2001), Service management and marketing: a customer relationship management approach. England: John Wiley and sons limited. 2nd edition.

Gujarati. (2006). Basic Econometrics (5th ed.). United States Military Academy, west point.

Kothari, C. R. (2004). Research Methodology: Methods and Techniques (2nd revised ed.). India: New Age International Publishers.

Machado, R. and Diggines, C. (2012). Customer Service. Juta \& Company Ltd.

Mason, R. D. \& Marchal, W. G. (2002). Statistical Techniques in Business and Economics. McGrawHill/Irwin, $11^{\text {th }}$ Edition.

Pallant, J. (2016). SPSS survival Manual. England: Open University press. 